Прегледни научни рад

УДК 82.02АВАНГАРДА

Примљен: 4. марта 2021.

Прихваћен: 26. марта 2021.

Милица П. Стојиљковић ${ }^{1}$

https://doi.org/10.46630/phm.13.2021.20

Универзитет у Нишу

Филозофски факултет

Департман за србистику

\title{
АВАНГАРДНА КЊИЖЕВНОСТ КАО СТИЛСКА ФОРМАЦИЈА
}

У раду се разматра поетика авангарде као опште појаве у првим деценијама 20. века. Најпре је указано на потребу периодизације како би се позиционирале књижевне и теоријске тенденције, а потом је извршено терминолошко одрећење. Авангарда је детермисана као стилска формација у сложеној номенклатури на основу решења Александра Флакера, а специфичности које су карактеристичне за књижевност овог доба показале су се неодвојивим од друштвено-историјског контекста. Промене које су настале након 19. века сматране су деструктивним и бунтовним због тежње ка аутентичности на свим плановима књижевноуметничког текста, али су допринеле томе да авангарда постане један од најинвентивнијих периода у историји књижевности.

Кључне речи: аванагарда, стилска формација, поетика, периодизација, двадесети век, жанр, Флакер

\section{1. Значај периодизације у проучавању књижевности}

Омеђивање одређених културних, уметничких, па и књижевних одлика у историјском следу не чини се као захвалан посао за проучаваоце који им приступају, посебно када се има на уму да је потребно најпре установити дијахронијски приступ заснован на оквирима, постулатима којих се треба придржавати, заједничким специфичностима, одликама. Чак и приликом периодизацијских омеђивања међу проучаваоцима се јављају опречни или недовољно прецизни ставови. Флакер говори (2011: 8) о утемељивачима литерарноисторијске периодизације наводећи примере по којима се може видети да је реч о процесу надодградње међу истомишљеницима, кроз време и генерације. Зачетником истиче Ричарда Мајера, немачког књижевника, који је 19. век поделио на десет целина створивши тиме „декадизацију” немачке књижевности. Оно што се 1 m.stojiljkovic-17789@filfak.ni.ac.rs 
може уочити као недостатак јесте одсуство критеријума по којима је ту поделу вршио. Ипак, можемо се сложити са тврдњом да „периодизација приказује грађу у јасно омеђеним временским одсјецима, а тиме истиче и континуитет и варијабилност развитка" (FLAKER 2011: 8). Неоспорно је да се приликом било какве периодизације мора узети у обзир скуп елемената који ће допринети омеђењу. Вилхелм Пиндер истиче да „повијест не треба схватити само као симултаност или сукцесију (Niberund Nacheinander) људских идеја и доживљаја [...] него као збивање које надвисује људску вољу" (PINDER, нав. према FLAKER 2011: 9), уводећи постепено појам стила који је неизоставна, „природна” појава (ISTO: 11) и који доприноси томе да „свако доба постаје вишегласни акорд стварања неколико генерација које се могу разликовати у циљевима, али се, такође, могу подударати у употреби једнаких средстава, па ће се из оваквог стања ствари развити стилски јединствена раздобља (ISTO)”.

Као што се може видети, још у првој половини 19. века почело је да се опсервира питање периодизације књижевности и начини који ће бити темељи. Поједини проучаваоци износе ставове по којима се књижевност не може посматрати независно од других уметности, политичког контекста или других националних књижевности (Хенри Пејр, прим. аут.), док на пример Велек и Ворен сматрају да се књижевност треба „утврдити чистим књижевним критеријем” (VELEK-VOREN 2004: 227), наглашавајући да је периодизација условљена искључиво књижевностилским одликама, а одбацајући тиме начела претходника да промене у периодима настају у контексту других, посредних или непосредних, утицаја - социјалних, економских, политичких или уметничких. О томе је првенствено говорио Тен заступањем детерминистичког метода приликом проучавања књижевности (а, у ширем контексту, и периодизације) наводећи расу, средину и моменат као кључне факторе за проучавалачки приступ сваком тексту. На његове постулате надовезао се и Павле Поповић, на самом почетку 20. века (1904), утемељивши у основи своје критике однос према средини и моменту. Потоње критичке школе донеле су нова решења и могућности, али је очигледно да је методолошки плуралитет антиципирао круцијалне тачке по којима периодизације мора бити; неоспорно је то да је она нужна појава по којој проучавање књижевноуметничких творевина не би имало конструктивни резултат и без које, свакако, стилских одлика не би могло бити, уколико се проматрају на нивоу „дела неке целине” (FLAKER 2011: 25)².

2 Под термином књижевни период подразумева се дужа временска целина у којој постоји јединство разнородних чинилаца, како књижевних или унутрашњих - формалних, стилских, жанровских или поетичких, тако и спољашњих или некњижевних чинилаца - друштвених, психолошких, идејних, културних, уметничких итд. (POPOVIĆ 2007: 354-355) 
1.2. Културно-историјске прилике на почетку 20. века

Почетак 20. века у књижевности европских земаља донео је различите тенденције. Оно што је заједничко свим покретима/правцима/ струјама/школама јесте апсолутна негација и „надилажење реалистичке поетике" (ŽIVKOVIĆ 1986: 11). Промене које су наступале засноване су на „игнорисању мимезиса, отпору према поетикама које почивају на овој теорији, налажењу духовних претеча у даљој или ближој прошлости, естетском превредновању света, а тиме и укључивање стваралаца у токове револуције" (ISTO: 10). Све је, дакле, повезано и не може се посматрати једно без другог, имплементација оквира спољашњег у унутрашње и обрнуто чини да је културно-историјске одлике потребно груписати како би се дошло до неких (оквирних, али постојаних) уопштавања. У вези са тим Флакер истиче да „епохе можемо описати само приближно и само [c] помоћу нужног избора битних црта; оне саме не постају повијесним битком” (2011: 13). Мада Велек истиче да је „период само етикета” (VELEK-VOREN 2004: 277), ипак, особености унутар неке групе чине се довољним да би одређени књижевно-уметнички покрети значајни, имеђу осталог, за предмет овог рада, а карактеристични за период пре и након Првог светског рата, добили номинализацију и били инкорпорирани у књижевноисторијски контекст.

\section{2. Терминолошка разграничења}

Проблематика са којом се сусрећемо приликом периодизације књижевности заснива се на терминолошким разграничењима појмова правца, епохе, струје, превасходно због неусаглашености у одређењима међу проучаваоцима, што због чињенице да поједине и потребне стилске црте нису уочљиве у истим књижевностима у истим добима, па се „због тога границе социјалнополитичких преокрета обично не подударају с границама књижевних периода" (FLAKER 2011: 31). Овај разлог, уколико занемаримо први (неусаглашеност ставова проучавалаца), доводи до различитих интерпретација терминологије и уоквиравања, односно груписања одређених стилских црта. Најпре, посебно је важно сложити се са Флакеровом констатацијом да „поједине стилске црте и синтетички појам периода стоје у вези, дијалектичкој вези којом су повезане цјелина и појединости” (према: 2011: 25), те да „нека стилска црта у једној стилској формацији дјелује на један начин, док друга значи друго и, у складу са тим, мора се интерпретирати у једном, односно другом смислу" (ISTO). На овај начин могуће је успоставити неки вид структурне хијерархије термина, издвајајући „макроструктуре” и „микроструктуре”. Држаћемо се Флакеровог минуциозног објашњења и ставова по којима су стилске 
формације надређени појам у односу на појам правца или струје. Он стилске формације посматра као„велика књижевноповијесна јединства која одлучују о карактеристикама и именовању појединих књижевних раздобља” (2011: 108), „стилска јединства настала као надиндивидуалне, a најчешће и наднационалне књижевноповијесне цјеловитости" (ISTO: 112), па је, према томе, диференцијација појмова логичан след који произилази из дефинисања овог термина. Као мање структуре Флакер издваја готово синонимне појмове „правац”/,струја” наводећи да би правцима требало „звати оне тенденције унутар књижевноповијеснога процеса које су се очитовале у одређено вријеме у књижевној критици [...]; правци настају у свијести одређених раздобља као посљедица дјелатности становитих књижевних покрета или скупина или се пак појављују као резултанта сродности у критичкој мисли одређенога времена..." (ISTO: 103). Ти микросиситеми настају као последица разграњавања стилске формације, особености које су понуђене у скупини обележја, маркираних најчешће изван оквира националних књижевности․․ Из овога произилази каузалитет између књижевности и историјских збивања, од социјалних фактора, различитих уметничких провенијенција и да је реч о узрочнопоследичној вези. Такође, посматрајући иманентне поетике конкретних писаца или жанрова, могуће је установити стилске особености и, даље, формирање стилских формација.

Структуралну хијерархију, као што се може видети, не карактерише једноставност нити пак наивност, јер се, осим ових појмова, периодизација заснива и на термину раздобља што антиципира даљу номинализацију. Када је реч о термину раздобља у контексту периодизације и стилских формација, Флакер истиче да се појмом периода „покрива мањи временски исјечак за који је карактеристична становита стилска групација, а термин епоха употребљавали бисмо тамо гдје он означује веће раздобље којим доминира становита стилска формација” (2011: 111).

Овим се само потврђује значај периодизације, као и то да проучавање књижевности није категоричан и непроменљиви процес.

2.1. Авангарда у контексту стилске формације

Превасходно бављење авангардологијом код Флакера резултирало је опсежним анализама овог појма у контексту свих релевантних чињеница које је опсервирао - на пољу уметности, књижевности, дру3 Треба имати на уму, истиче Флакер, да „националне модификације појединих праваца не значе увијек њихову истоветност у различитим националним књижевностима нити воде увијек према стилском јединству." (2011: 104) О овом ексцесу стилских формација биће речи у потоњим сегментима рада када се буде говорило о авангарди. 
штвено-ангажованих појава, дијахронији и синхронији, историјском контексту. Посматрајаћи авангарду у оквиру раздобља (о којима је, такође, говорио у својим есејима), извршио је периодизацију (књижевних) појава на време 1910-1930. године ${ }^{4}$. Оваква конкретизација временског следа делује изненађујуће с обзиром на неслагања (и чак противуречности) која се јављају међу еминентним проучаваоцима књижевних појава насталих након реализма, а у зависности од географског фактора. ${ }^{5}$ Задржавајући се превасходно на терминолошкој детерминацији књижевних појава у поменутом периоду, Флакер даје само хронолошки преглед појава и праваца који су непосредно претходили авангарди (пре 1910). ${ }^{6}$

Круцијални термин којим дефинише своје ставове о авангарди увео је како би окарактерисао „структуре настале услијед распадања реалистичких облика" (FLAKER 2011: 58). Појмом дезинтеграција реализма (ин)директно одбацује све понуђене термине у периодизацији пре авангарде и на тренутак одступа од изванкњижевних фактора, држећи се искључиво структурних одлика. У вези са тим наводи раздобље модерне (уважавајући и термин модерна књижевност), оспоравајући јој могућност уврштавања у стилску формацију ${ }^{7}$ (ISTO: 59), и истиче да би „појам имао покривати с једне стране распадање реалистичких структура, а с друге стране све оне новотворбе које у источној Европи настају услијед напуштања националне функције књижевостиу традиционалном смислу схваћања такве функције, одбијања социјалноаналитичких функциja, наглашенога признавања естетских функција и оријентације на 'модерне' моделе [францускога пјесништва]...” (FLAKER 2011: 146). О појму модернизам посебни осврт дао је Жирмунски који је нагињао друштвено-историјском приступу проучавања књижевности, супротстављајући се „иманентном” и „формалистичком” проучавању књижевне еволуције

4 Флакерова намера била је да се авангарда детерминише као „плодно 'уметничко раздобље' које се одређује на основу уметничких остварења, са што мање уобичајених уопштавања, али са довољном теоријском образложеношћу”. (ŽIVKOVIĆ 1986: 10)

5 О томе да се у источнословенским, западнословенским и јужнословенским књижевностима употребљавала различита терминологија говори и сам Флакер; оспоравајући, чини се, сваку могућу номинализацију.

6 Симболизам (држећи се Велекових ставова) омеђује на период 1885-1911. и везује га за територију Француске говорећи да се тим појмом могу „карактеризират само оне релативо ријетке структуре које том појму заиста одговарају” (према: 2011: 61), док истиче као недовољно прецизан и добар појам употребљаван у словенским књижевностима - неоромантизам. (ISTO: 56-57) Појам импресионизма везује за натурализам западноевропских књижевности, немачке првенствено, а сецесију готово да поистовећује са појмом неокласицизма, држећи се одређења Марије Бобровницке у оквирима пољске књижевности. (ISTO: 64)

7 Легитимним прихвата и појам „секундарни стил” којим се служи Лихачов, истичући да је реч о „стилском англомерату подудардном појму модерне”. (FLAKER 2011: 63) 
истицањем да модернизам „уједињује различите мање скупине 'микросистема' које су заправо само дио 'универзалног макросистема' (нав. према: ŽIRMUNSKI: 3, 7, 11 у: FLAKER 2011: 50).

Дакле, ставови неприкосновеног слависте-проучаваоца авангарде и периодизације књижевности приказују неминовност прожимања унутрашњих и спољашњих фактора.

\section{2. Одлике авангардне стилске формације у књижевности}

Ако посматрамо авангарду у оквиру „структуре структура”, дакле, само на унутрашњем, структуралистичком и тематском нивоу, ван оквира омеђивања (периодизацијског идетерминацијског), важно је истаћи поједине особине, стилске компоненте које представљају скуп заједничких црта већег дела авангардних остварења. При томе, потребно је имати у виду, сложићемо се са Флакеровим мишљењем, да овакве стилске формације - обимне попут авангарде - показују кохерентност у неким, док у другим аспектима испољавају разноликост. (2011: 109) То је и очекивано ако се узме у обзир да се „модели једне стилске формације шире изван националних књижевости у којима су настали, они захваћају књижевности других језика и нација, али у њима они губе низ својих функција, попримају друге функције и доживљавају значајне и осебујне трансформације и модификације. Наднационална стилска формација (у овом случају авангарда, прим. аут.) задржава тада у својим различитим националним појавним облицима своје битне структуралне особине, али се оне једним делом нарушавају или мијењају у складу са специфичним функцијама унутар појединих националних друштвених организама” (ISTO: 128). Дакако да се у свакој националној књижевности издвајају неке одлике којих нема у другим у складу са претензијама аутора и њиховим стилско-тематским решењима, али је могуће успоставити преглед који је карактеристичан за сва подручја стварања. Не задржавајући се на посебним -измима ${ }^{8}$ који су се издвојили својим специфичностима, авангардна књижевност као „макросустав”9 је, према утврђеном мишљењу, „став побуне и незадовољства” (PALAVESTRA 1979: 175), скуп другачијег покољења „непомирљиве рушилачке одлучности, бунтовно, дивље, неспретно (?) и непокорно, пуно револуционарног динамизма, решено да се супротстави свим водећим ауторитетима..” (ISTO: 178). Можемо се сложити са Калинесковим тумачењем по којем је „авангарда негде два8 Можемо рећи и књижевним правцима у контексту означавања кретања унутар једне или више националних књижевности, која се, даље, „испољују у преношењу појединих структуралних елемената из једне у другу структуру, из једног књижевног опуса у други, из једне књижевности у другу" чинећи тако надиндивидуалне формације (према: FLAKER 2011: 94).

9 Флакерова одредница. 
десетих година 20. века као уметнички концепт постала довољно свеобухватна да је собом могла да означи не ову или ону, већ све нове школе чије је програме, узевши све у обзир, карактерисало одбацивање прошлости и неговање култа новог" (KALINESKU: 132 у: TEŠIĆ: 1997). Аванагарда je, дакле, имала тенденцију да твори продукте прожете „естетском провокацијом чиме би се изазвао 'шок' или наишло на отпоре примаоца” (ŽIVKOVIĆ 1986: 12), што пружа могућност за бројне варијације у теорији рецепције. Хоризонт очекивањ ${ }^{10}$ у оваквом случају је посве индивидуализован и појављује се као вредносни суд у естетици рецепције.

Коегзистенција социјално-ангажованих појава и идеолошких (личних) ставова аутора авангарде не мора (и не треба увек) бити основа за методолошке интенције проучаваоца. Ипак, често се дешава да „ангажовано потискује лепо" (ŽIVKOVIĆ 1986: 16), па у складу са тим ствара се погодно тле за варијабилност тумачења. ${ }^{11}$ Агресивност која је прокламована кроз програме и уметничка дела, авангарду је, у појединим аспектима, издигла до ентитета рушилачког ${ }^{12}$.

Интересантан приступ даје Виктор Жмегач говрећи о појму модернизма као ознаци за све појаве које су претходиле авангарди („за тзв. модерну (завршне деценије прошлог века), и за књижевна струјања на почетку нашега века (двадесетог, прим. аут.), као и за разнородна а истосмерна стремљења у књижевности и уметности након Првог светског рата, односно, и за књижевност/уметност које уобичајено означавамо као савремену или текућу”) (ŽMEGAČ, нав. према: ŽIVKOVIĆ 1986: 25). Дајући примат модернизму над појмом авангарда, Жмегач децидирано оспорава одређење појава за које смо се определили да припадају периоду 1910-1930, па се, из тог разлога, овај термин не може примењивати у нашем проучавању. Када је реч о иманентним погледима на поетику модернизма (авангарде, у овом случају), Жмегач издваја „негацију традиције и реалистичко-натуралистичке поетике, као и тежњу да се избори аутономија уметности (и уметника!) и да се прошире и револуционишу слободе какве је прописао 'bourgeois', грађанин" (ISTO: 26), о чему је већ било помена, те се овакви видови тумачења могу сматрати релевантним. Говорећи даље о појавама које се односе на почетак 20. века истиче Бодлерово антимиметичко преферирање уметности (чина и дела), те сма-

10 Ханс Роберт Јаус први је увео појмове естетика рецепције у контексту хоризонта очекивања, 1967. године. О томе детаљније у: JAUS 1978.

11 Дакле, готово да је немогуће придржавати се само иманентног и(ли) само формалистичког проучавања, јер се авангардистичке тенденције прожимају са факторима који су инфилтрирани (не)посредно кроз друштвену стварност и догађаје који су обележили ово раздобље.

12 „У авангарним покретима понекад се пренаглашава преврат, односно тотални раскид с традицијом.” (ŽMEGAČ, нав. према: ŽIVKOVIĆ 1986: 26) 
тра да су антимиметизам прихватили и авангардисти свих „боја” (ISTO: 27). Ипак, прихватамо став да је авангарда стилска формација, надређени појам којим се означавају „они књижевни покрети који су се под тим именом јављали у европским уметностима између прве и треће деценије нашега века (експресионизам, футуризам, дадаизам, надреализам и слично)...” (ŽIVKOVIĆ 1986: 32) и да се ова формација манифестовала експлицитним (манифести) и имплицитним поетикама (уметничка остварења $)^{13}$ (ISTO).

Дакле, несумњиво је да се унутар авангарде јављају поједини -изми у различитим облицима разноврсних књижевности (о чему је било речи; елементи једне поетике инкорпорирају се у друге, и обрнуто) и они су хијерархијски подређени појму стилска формација, па се одређују као покрети/правци. Сваки од њих има авангардистичке интенције, али интерпретиране кроз сопствену призму превредновања света и уметности. ${ }^{14}$

У контексту опште појаве авангардне уметности ${ }^{15}$ „можемо чак рећи да је авангардна идеологија друштвена појава управо због друштвеног или антидруштвеног карактера културних и уметничких испољавања, које подржава и изражава” (POĐOLI: 21 y: TEŠIĆ 1997) jep je „идеологија увек друштвена појава” (ISTO). Авангарда је у периоду своје експанзије постала начин живљења, принцип којег су се придржавали заговорници, а тај принцип заснивао се на „нападу, полемици, борби, заузимању превазиђених, застарелих позиција на јуриш, жестоко и радикално рушење препрека. (Jep) Авангарда јесте и треба да буде агресивна или је нема"16 (MORINO: 42 у: TEŠIĆ 1997). Авангарда у првим деценија-

13 Занимљиво је то да Флакер манифесте не узима као репрезентативне примере за тумачење поетике авангарде, са чим се не бисмо могли у потпуности сложити.

14 Боленбек истиче да и „поред појединих -изама (између осталих, футуризам, кувизам, експресионизам, конструктивизам, дадаизама, надреализам, чешки поетизам, руски леф, имажинизам) који већином имају националне центре, ипак је авангарда интернационална појава, која, превазилазећи границе родова, обухвата уметност, књижевност, музику, архитектуру и дизајн”. (BOLENBEK: 145 у: TEŠIĆ 1997)

15 Или, како ју је називао Виторио Пика „уметност (или књижевност) изузетка”. (према: POĐOLI: 21 у: TEŠIĆ 1997)

16 У вези са тим требало би подсетити да назив авангарда потиче из војне метафоре којом је насловљена, како наводи Марино, прва „авангардистичка“ публикација L'Avantgarde de l'Armée des Pyrénées orientales (крајем 18. века, 1794), настала као производ пропагандног полета Француске револуције, „чије гесло је написано на оштрици симболичног мача и гласи: „La liberte ou la mort” („Слобода или смрт”) (KALINESKU: 113 y:TEŠIĆ 1997). „Авангарда представља малу 'ударну’ групу, јединицу командоса, предузимљиву, одважну и енергичну, која се провлачи кроз линије непријатеља суочавајући се са многим ризицима и препрекама, крчећи пут војсци у напредовању. (Стога) Преузимање идеје се објашњава на исти начин: прогресивне, револуционарне друштвене снаге у 〈авангарди〉 су, по дефиницији, офанзивне.” (MORINO: 39 у: TEŠIĆ 1997) Калинеску додатно објашњава да и у „другим језицима, нарочито новолатинским, одговарајући 
ма 20. века постаје духовна номенклатура која превазилази оквире књижевно-уметничког дејствовања.

\section{3. Закључна разматрања}

У историји књижевности (и културе) никада ниједна књижевно-уметничка епоха није изнедрила више противуречних, а ипак јединствених остварења као што је то учинила авангарда у првим деценијама 20. века. ${ }^{17}$ Авангардистичка стилска формација сматра(ла) се надасве необичном, (не)очекиваном и изаз(и)вала је ефекат шока свим својим доктринистичким -измима. Књижевници тога доба управо су то имали на уму стварајући дела у којима се негирају жанровске конвенције, устаљена композициона решења, стилско јединство. Новом добу, добу процвата технологије, али и ратом разореним бићима, била је потребна нова култура, али и посве другачији уметнички домети. Свет је у сваком погледу вапио за променама и развојем, па су и уметници кренули да делују у том правцу. Из таквих тежњи и контемплација, произишлих из реакција на друштвено-историјске прилике, створена су аванагардистичка дела којима су изражаване (не)скривене интенције аутора у вези са свим спољашњим утицајима, који су, посредно или непосредно, допринели одабиру одређених преференција. Дошло је до бунта, револуције и промена у књижевности (и уметности уопште) којима је изражавано незадовољство, никако рушилачког и уништавајућег карактера. Циљ је био стварати дела којима се може подстицати активизам на свим животним пољима, а аутори су, попут неких прокламатора, ширили своје идеје посредством сопствених поетичких начела (имплицитно или експлицитно). Због тога, авангарда као стилска формација не може бити посматрана симплификовано, нити ван оквира друштвено-историјског контекста, односно „у оквиру психологије и идеологије” (POĐOLI: 23 у: TEŠIĆ 1997), које су утицале на њено стварање (и трајање).

Комплексност авангардистичких доктрина уочава се у свим жанровским решењима којима су се ствараоци служили у својим револуционарним мисијама. Детерминација свих (до тада) постојећих облика мора се узети са резервом јер је дошло до значајних промена и у геноло-

појмови (avangardia у италијанском или vangardia у шпанском) развили су своја метафорична значења тек накнадно и несумњиво по угледу на пример из француског језика. И енглеска реч vanguard означава на првом месту „трупе које се крећу на челу војске” (Webster's New Collegiate Dictionary, 1973). Дакле, „метафорично значење 'претходнице некој акцији или покрету' долази тек на друго место” (KALINESKU: 112 y: TEŠIĆ 1997).

17 Постмодернизам касније изнедрио је, несумњиво, изузетне творевине, али се у погледу иновација не може равнати са авангардном поетиком и њеним специфичним остварењима. 
шком смислу. Као и свака нова епоха, и авангарда је изискивала познавање дијахронијског развоја жанрова, међутим, њена специфичност огледа се и у чињеници да је и на синхронијском плану потребно успостављати (ко)релације због израженог методолошког плуралитета који је владао међу ствараоцима.

У раду је указано на потребу периодизације, а потом је извршено омеђивање стилске формације у сложеној номенклатури, где су понуђена номинализацијска решења. Промене које је авангарда изнедрила (у складу са својим тенденцијама) односе се на (наизглед) рушилачке интенције, међутим, авангарда није била наклоњена уништавању нити пак негирању постојећих вредности, она је само тежила сукцесивним променама. Кореспонденција форме са претходним традиционалистичким облицима допринела је томе да се методолошке могућности аутора изразе различитим формама. „Склоност ка сталном ослобађању израза, облика и композиције” (MORINO: 80 y: TEŠIĆ 1997) радикализује теорију рецепције и перцепције и на тај начин поставља индивидуалност сваког ствараоца засебно оспоравајући могућност естетике истоветности.

Тежња ка аутентичности изражена је не само у епохи авангарде, али је у њој достигла врхунац. Са исте стране, аподиктичном се намеће варијабилност у свим структурним поступцима и баш из тог разлога, период 1910-1930. можемо сматрати најиновативнијим периодом у историји књижевности.

\section{Цитирана литература}

ARISTOTEL 2002: ARISTOTEL. O pesničkoj umetnosti. Prev. Miloš N. Đurić. Beograd: Dereta, 2002. [orig.] АРИСТОТЕЛ. О песничкој уметности. Прев. Милош Н. Ђурић. Београд: Дерета, 2002.

BAHTIN 1989: BAHTIN, Mihail. O romanu. Prev. Aleksandar Badnjarević. Beograd: Nolit, 1989. [orig.] БАХТИН, Михаил. О роману. Прев. Александар Бадњаревић. Београд: Нолит, 1989.

BAHTIN 1967: BAHTIN, Mihail. Problemi poetike Dostojevskog. Beograd: Nolit, 1967. [orig.] БАХТИН, Михаил. Проблеми поетике Достојевског. Београд: Нолит, 1967.

BIRGER 1998: BIRGER, Peter. Teorija avangarde. Prev. Zoran Milutinović. Beograd: Narodna knjiga - Alfa, 1998. [orig.] БИРГЕР, Петер. Теорија авангарде. Прев. Зоран Милутиновић. Београд: Народна књига - Алфа, 1998.

FLAKER 2011: FLAKER, Aleksandar. Period, stil, žanr. - 1. izd. Beograd: Službeni glasnik, 2011. [orig.] ФЛАКЕР, Александар. Период, стил, жанр. - 1. изд. Београд: Службени гласник, 2011.

HAMVAŠ 1996: HAMVAŠ, Bela. Teorija romana. Prev. Sava Babić. Beograd: SKC, 1996. [orig.] ХАМВАШ, Бела. Теорија романа. Прев. Сава Бабић. Београд: СКЦ, 1996. 
JAUS 1987: JAUS, Hans Robert. Estetika recepcije, izbor studija. Prev. Drinka Gojković. Beograd: Nolit, 1978. [orig.] JАУС, Ханс Роберт. Естетика рецепиије, избор студија. Прев. Дринка Гојковић. Београд: Нолит, 1978.

LUKAČ 1990: LUKAČ, Đerđ. Teorija romana. - 2. izd. Ur. Abdulah Šarčević. Prev. Kasim Prohić. Sarajevo: Veselin Masleša - Svjetlost, 1990. [orig.] ЛУКАЧ, Ђерђ. Теорија романа. - 2. изд. Ур. Абдулах Шарчевић. Прев. Касим Прохић. Сарајево: Веселин Маслеша - Свјетлост, 1990.

MILUTINOVIĆ 2009: MILUTINOVIĆ, Dejan. „Žanr - pojam, istorija, teorija”. Philologia Mediana, god. 1. br. 1 (2009): str. 11-39. МИЛУТИНОВИЋ, Дејан. „Жанр - појам, историја, теорија”. Philologia Mediana, год. 1, бр. 1 (2009): стр. 11- 39.

PALAVESTRA 1979: PALAVESTRA, Predrag. Kritika $i$ avangarda u modernoj srpskoj književnosti. Književne teme VI. Beograd: Prosveta, 1979. [orig.] ПАЛАВЕСТРА, Предраг. Критика и авангарда у модерној српској књижевности. Књижевне теме VI. Београд: Просвета, 1979.

PETROVIĆ 2008: PETROVIĆ, Predrag. Avangardni roman bez romana. (Poetika kratkog romana srpske avangarde). - 1. izd. Ur. Novica Petković. Beograd: Institut za književnost i umetnost, 2008. [orig.] ПЕТРОВИЋ, Предраг. Авангардни роман без романа. (Поетика кратког романа српске авангарде). - 1. изд. Ур. Новица Петковић. Београд: Институт за књижевност и уметност, 2008.

POPOVIĆ 2007: POPOVIĆ, Tanja. Rečnik književnih termina. - 1. izd. Beograd: Logos Art, 2007. [orig.] ПОПОВИЋ, Тања. Речник кюижевних термина. - 1. изд. Београд: Логос Арт, 2007.

TEŠIĆ 1997: TEŠIĆ, Gojko. Avangarda.Teorija I istorija pojma. Beograd: Narodna knjiga, 1997. [orig.] ТЕШИЋ, Гојко. Авангарда.Теорија и историја појма. Београд: Народна књига, 1997.

TORE 2001: TORE, Giljermo. Istorija avangardnih književnosti. Sremski Karlovci Novi Sad: Izdavačka knjižarnica Zorana Stojanovića, 2001. [orig.] TOPE, Гиљермо. Историја авангардних книжевности. Сремски Карловци Нови Сад: Издавачка књижарница Зорана Стојановића, 2001.

VELEK-VOREN 2004: VELEK, Rene i Ostin VOREN. Teorija književnosti. Prev. Aleksandar Spasić i Slobodan Đorđević. - 1. izd. Beograd: Utopija, 2004. [orig.] ВЕЛЕК, Рене и Остин ВОРЕН. Теорија кюижевности. Прев. Александар Спасић и Слободан Ђорђевић. - 1. изд. Београд: Утопија, 2004.

VUČKOVIĆ 2011a: VUČKOVIĆ, Radovan. Poetika srpske avangarde (Ekspresionizam). Ur. Gojko Tešić. Beograd: Službeni glasnik, 2011. [orig.] ВУЧКОВИЋ, Радован. Поетика српске авангарде(Експерсионизам). Ур. Гојко Тешић. Београд: Службени гласник, 2011.

VUČKOVIĆ 2011b: VUČKOVIĆ, Radovan. Proza srpske avangarde. Ur. Gojko Tešić. Beograd: Službeni glasnik, 2011. [orig.] ВУчКОВИЋ, Радован, Проза српске авангарде. Ур. Гојко Тешић. Београд: Службени гласник, 2011.

ŽIVKOVIĆ 1986: ŽIVKOVIĆ, Živan. Izazovi avangarde. Beograd: Novo delo, 1986. [orig.] ЖИВКОВИЋ, Живан. Изазови авангарде. Београд: Ново дело, 
1986.

ŽMEGAČ 1987: ŽMEGAČ, Viktor. Povijesna poetika romana. Sarajevo: Grafički zavod Hrvatske, 1987. [orig.] ЖМЕГАЧ, Виктор. Повијесна поетика романа. Сарајево: Графички завод Хрватске, 1987.

Milica P. Stojiljković

\section{AVANT-GARDE LITERATURE AS A STYLISTIC FORMATION}

This paper discusses the poetics of the avant-garde as a general phenomenon in the first decades of the $20^{\text {th }}$ century. First, the need for periodization was pointed out in order to position literary and theoretical tendencies, and then a terminological determination was made. The avant-garde was determined as a stylistic formation in a complex nomenclature based on the solution of Alexander Flaker, and the specifics that are characteristic of the literature of this era proved to be inseparable from the socio-historical context of literature. The changes that took place after the $19^{\text {th }}$ century were considered destructive and rebellious due to the striving for authenticity on all levels of the literary and artistic text, but they contributed to the avant-garde becoming one of the most inventive periods in the history of literature.

Keywords: avant-garde, stylistic formation, poetics, periodization, twentieth century, genre, Flaker 